Geological Survey (Scotland); Dr. J.-B. O. Sneeden, lecturer on heat engines, Royal Technical College, Glasgow ; Dr. W. E. Swinton, curator of fossil reptiles and amphibia, British Museum (Natural History); Henry Wade, senior lecturer in clinical surgery, University of Edinburgh.

\section{Royal Horticultural Society}

THE unveiling of a plaque commemorating the foundation of the Horticultural Society in 1804 (designated 'Royal' in 1861, during the presidency of the Prince Consort), the initial proceedings of which were conducted in a room at Messrs. Hatchards, booksellers, Piccadilly, London, was the occasion of a representative gathering on March 7 at the firm's establishment, which is on the site of the older house. It is claimed that London annals do not provide any precedent recording in this way the foundation of a society having scientific relationships. The plaque has been placed on the face of the building in Piccadilly, whilst an illuminated record, inscribed with the names of the original promoters, is placed inside. These were: The Right Hon. Charles Greville, Sir Joseph Banks, John Wedgwood, R. A. Salisbury, W. T. Aiton, William Forsyth, and James Dickson. The unveiling ceremony was performed by the Hon. Henry McLaren, president of the Society, and Mr. Gerald Loder, past president.

Ar the original meeting of the Horticultural Society in 1804, John Wedgwood (1766-1844) was chairman. He was the eldest son of the illustrious Josiah Wedg. wood, and was strongly attached to horticulture, notwithstanding the limitations of the period. An early paper of his dealt with the propagation of dahlias. Some proposals that Wedgwood drew up, accompanied by useful notes, were largely instrumental in bringing the Society into being. He had observed the rise of societies for the improvement of agriculture-the British Mineralogical Society of that time was actively engaged in examining specimens of earths or soils to aid the science of husbandry-but no organisation existed for the sole purpose of encouraging horticulture. Hence, the object of the newly formed Society was the collection of information respecting the culture and treatment, culinary as well as ornamental, of plants and trees, and the publication of papers on horticultural subjects. From modest beginnings, the Society has now achieved a membership of 27,000.

\section{Faraday's Work in Electrochemistry}

The subject of Sir Harold Hartley's Friday evening discourse at the Royal Institution on March 4 was "Michael Faraday and Electrochemistry". From 1832 until 1834 Faraday was mainly occupied with electrochemical researches. He first showed that amounts of electricity which produced the same effect on a galvanometer also liberated the same amount of iodine when passed through a solution of potassium iodide. He then went on to systematic investigation of the amounts of different elements which are liberated when the same current is passed through a series of solutions or fused substances, and established the two fundamental laws of electrolysis which still stand as the quantitative basis of electrochemistry. $\mathrm{He}$ investigated also the mechanism by which a current passes through an electrolyte, and his ideas were crystallised in the nomenclature which he devised with the help of Whewell. All his new names-ion, anion, cation, electrode, and electrolysis-we use to-day with the significance which Faraday gave to them. In addition, he explored the source of the energy of the voltaic cell and forecast its relation to the affinity of the chemical reaction taking place in the cell. With the help of extracts from Faraday's diary, Sir Harold traced the development of Faraday's electrochemical work, repeating the decisive experiments which were the milestones of its progress. Faraday's electrochemical researches rank among the highest of his achievements. They were carried out in a short space of time with amazing economy of effort--it took him only two days to establish a connexion between the quantity of electricity and the amount of chemical action due to it-thanks to the combination in Faraday of brilliant imagination, unerring instinct for essentials, and unrivalled mastery of experimental technique; and his main conclusions still hold good to-day.

\section{The Aryans}

Sir ARTHur KeIth's Frazer lecture on "The Aryan Theory as it stands To-day", which was delivered in the University of Glasgow on March 4, was lacking neither in courage nor in imagination. Much water has passed under the bridge since Max Müller was accused of confusing race and language. Sir Arthur, holding that race and language are two aspects of one problem, nevertheless admits that for clearness we should have one name for the languages of Europe and another for its peoples, namely 'Caucasian'. From a reconsideration of the problem in the light of the evidence which has accrued recently from Ur, Kish, and Susa, and a survey of the distribution of racial types in early times, he derives the Caucasians from the plateau extending from Mesopotamia to India, for which he suggests the name 'Gedrosian'. In rejecting Europe as the place of origin of the Aryan tongues and practically reverting to the area west of the Pamirs put forward by Max Müller, Sir Arthur relies on the evidence of prehistory that down to somewhere about 3000 B.c. the culture of Europe was of too rudimentary a type and its inhabitants too few to make it probable that migration was to, rather than from, the highly organised agricultural communities of the east. It will be seen that Sir Arthur gave his hearers much material for careful pondering, his views implying a frank acceptance of racial and linguistic anomalies difficult to explain on any theory. He went further and asked of the Aryan theory that it should explain the triple racial zone of Europe and the diffusion of the Aryan tongues.

\section{Forecast and Fact in Science}

THE fourteenth annual Earl Grey Memorial lecture of Armstrong College (University of Durham) was given on March 3 by Dr. R. A. Sampson, Astronomer 